\title{
IMPLEMENTASI MODEL PEMBELAJARAN KOOPERATIF TIPE JIGSAW UNTUK MENINGKATKAN HASIL BELAJAR SISWA PADA KOMPETENSI DASAR PERAWATAN KOPLING
}

\author{
Alfatah Hidayat ${ }^{1}$, Ono Wiharna', Yusep Sukrawan ${ }^{3}$ \\ Departemen Pendidikan Teknik Mesin \\ Universitas Pendidikan Indonesia \\ Jl. Dr. Setiabudhi No. 207 Bandung 40154 \\ atheruzy@gmail.com
}

\begin{abstract}
ABSTRAK
Tujuan penelitian ini untuk mengetahui efektitvitas implementasi model pembelajaran kooperatif tipe jigsaw dalam meningkatkan aktivitas belajar siswa kelas SMK pada kompetensi dasar perawatan kopling, untuk mengetahui peningkatan hasil belajar dalam kompetensi dasar perawatan kopling dengan implementasi model pembelajaran kooperatif tipe jigsaw. Metode penelitian yang digunakan adalah metode eksperimen semu (quasi experiment) dengan desain penelitian yang digunakan yaitu nonequivalent control group design. Sampel yang digunakan dalam penelitian ini adalah siswa kelas XI TKR di SMK Negeri 8 Bandung dengan kelas XI TKR 2 sebagai kelas kontrol dan kelas XI TKR 3 sebagai kelas eksperimen. Hasil penelitian menunjukkan adanya peningkatan hasil belajar siswa. Peningkatan hasil belajar siswa berdasarkan aspek kognitif, psikomotorik, dan afektif dapat disimpulkan sebanyak 32\%. Sehingga model pembelajaran kooperatif tipe jigsaw ini memberikan dampak positif terhadap peningkatan hasil belajar siswa.
\end{abstract}

Kata kunci: jigsaw, perawatan, kopling, kooperatif, kompetensi.

\section{PENDAHULUAN}

Pendidikan merupakan hal yang paling penting bagi individu, bahwa setiap manusia berhak mendapatkannya dan diharapkan untuk selalu berkembang di dalamnya. Pendidikan tidak bisa terlepas dari proses belajar mengajar. Oleh karena itu, keduanya saling berkaitan untuk mencapai tujuan akhir pembelajaran. Kualitas pembelajaran yang baik akan tercapai apabila proses pembelajaran berjalan dengan efektif dan efisien untuk mencapai tujuan pembelajaran (Sudjana, 2014). Di Indonesia, tujuan Pendidikan Nasional bersumber dari sistem nilai Pancasila dirumuskan dalam UU No 20 tahun 2003 khususnya pasal 3, bahwa Pendidikan Nasional berfungsi mengembangkan kemampuan dan membentuk watak serta peradaban bangsa yang bermartabat dalam rangka mencerdaskan kehidupan bangsa, bertujuan untuk berkembangnya potensi peserta didik agar menjadi manusia yang beriman dan bertaqwa kepada Tuhan Yang Maha Esa, berakhlak mulia, sehat, berilmu, cakap, kreatif , mandiri dan menjadi warga Negara yang demokratis serta bertanggung jawab terhadap dirinya, masyarakat dan bangsanya.

\footnotetext{
${ }^{1}$ Mahasiswa Departemen Pendidikan Teknik Mesin FPTK UPI

${ }^{2}$ Dosen Departemen Pendidikan Teknik Mesin FPTK UPI

${ }^{3}$ Dosen Departemen Pendidikan Teknik Mesin FPTK UPI
} 
Mencapai tujuan pembelajaran tersebut, kompetensi siswa disesuaikan dengan kebutuhan, minat, dan bakat serta potensi yang dimilikinya sesuai dengan kebutuhan lingkungannya. Keberhasilan pencapaian tujuan pembelajaran dapat terlihat dari proses pembelajaran guru yang berhadapan langsung dengan siswa. Pemerintah berupaya untuk mengubah sistem pendidikan nasional. Selain mengubah sistem pendidikan nasional, adakalanya mengubah model pembelajaran, materi, model, serta guru.

Perkembangan dunia pendidikan mengalami banyak faktor permasalahan, salah satu masalah yang paling penting adalah kualitas pendidikan. Kualitas pendidikan sering dikaitkan dengan hasil belajar yang diperoleh siswa dan tidak terlepas dari kualitas proses pembelajaran yang dilakukan oleh guru. Keberhasilan belajar seseorang dipengaruhi oleh banyak faktor diantaranya faktor internal (dari dalam diri siswa) dan faktor eksternal (dari luar diri siswa), faktor dari dalam siswa adalah faktor yang sangat penting untuk menentukan hasil belajar siswa (Slameto, 2013). Hal tersebut dapat dimengerti karena siswa adalah sebagai objek sarana belajar. Setiap siswa memiliki kemampuan yang berbeda dalam menyerap materi yang diajarkan oleh guru. Peran guru sangat penting agar siswa dapat mengikuti pelajaran dan timbul rasa suka dalam pelajaran tersebut. Guru harus dapat menimbulkan rasa motivasi untuk belajar bagi siswa mengarahkan siswa agar dapat belajar tanpa ada paksaan. Faktor model pembelajaran mempunyai peran yang besar dalam usaha mencapai tujuan pembelajaran, termasuk pembelajaran pada mata pelajaran chassis dan pemindahan tenaga.

Mata pelajaran chassis dan pemindahan tenaga merupakan mata pelajaran yang membahas mengenai kopling, diferensial, dan transmisi. Mata pelajaran chassis dan pemindahan tenaga merupakan mata pelajaran wajib yang harus dipelajari oleh siswa kelas XI di SMK. Materi yang dipelajari pada mata pelajaran ini tentang perawatan pada kopling, dimana siswa mempelajari mengenai prinsip kerja, cara kerja, fungsi bagian dari komponen kopling, cara membongkar, cara memeriksa, cara perawatan, cara perakitan, dan jenis-jenis kopling. Sehingga pada saat mempelajari materi kopling siswa harus menguasai materi, tetapi pada kenyataannya siswa belum dapat menguasai materi tersebut sehingga berdampak pada hasil belajar yang belum optimal.

Berdasarkan hasil sirvei awal di SMK Negeri 8 Bandung, didapatkan bahwa kebanyakan pembelajaran produktif masih menggunakan model pembelajaran klasikal dengan metode ceramah. Keberhasilan pencapaian tujuan pembelajaran, salah satunya dapat dilihat dari hasil belajar siswa, sebagai studi kasus yaitu hasil ulangan harian kelas XI TKR SMK Negeri 8 Bandung. Hasil ulangan harian dapat dikatakan bahwa nilai siswa 
belum memenuhi KKM yaitu 2,67 (kriteria ketuntasan minimal). Hasil ulangan harian menunjukkan bahwa siswa yang lulus ulangan harian hanya 33.3\% dari jumlah 60 siswa pada mata pelajaran chassis dan pemindahan tenaga tergolong rendah. Hal ini didapat dilihat dari rendahnya nilai rata-rata siswa. Rendahnya hasil belajar siswa disebabkan beberapa faktor. Secara garis besar, faktor yang mempengaruhi hasil belajar meliputi faktor eksternal dan faktor internal. Faktor eksternal meliputi cara orang tua mendidik, keadaan ekonomi keluarga, model pembelajaran pada saat kegiatan belajar mengajar, alat evaluasi, lingkungan belajar, media pengajaran, media masa dan lain-lain, sedangkan faktor internal meliputi faktor kesehatan, bakat, motivasi, sikap, perhatian, kematangan, kesiapan dan lain-lain. Hasil belajar siswa dapat dipengaruhi oleh model pembelajaran yang digunakan oleh guru di dalam kelas. Setiap guru hendaknya menentukan model pembelajaran yang paling sesuai dengan materi yang disampaikan (Pribadi, 2010). Faktor model pembelajaran mempunyai peran yang besar dalam usaha mencapai tujuan pembelajaran, termasuk pembelajaran pada mata pelajaran chassis dan pemindahan tenaga.

Kurikulum yang digunakan oleh SMKN 8 Bandung yaitu kurikulum 2013, dimana pelaksanaan pembelajaran harus berpusat pada siswa. Melalui studi pendahuluan pada proses pembelajaran mata pelajaran chassis dan pemindahan tenaga masih menggunakan sistem pembelajaran klasikal dengan metode ceramah. Sehingga siswa kurang aktif dalam kegiatan belajar mengajar, siswa hanya mencatat, dan masih berpusat pada guru (teacher centre). Kondisi pembelajaran menyebabkan siswa tidak aktif dalam mengajukan pertanyaan, mengajukan pendapat, dan mengerjakan tugas mandiri dan kelompok. Permasalahan tersebut juga terlihat dari hasil nilai ulangan harian maupun nilai ujian tengah semester. Disinilah peran guru untuk merancang kegiatan pembelajaran yang mampu mengembangkan kompetensi, baik ranah kognitif, psikomotorik, maupun afektif. Sehingga strategi pembelajaran yang berpusat pada siswa dan menciptakan suasana yang menyenangkan.

Salah satu upaya agar siswa dapat mengikuti proses pembelajaran secara aktif yaitu guru harus lebih cermat dalam menggunakan suatu model pembelajaran. Penggunaan model yang tepat dalam pembelajaran dapat menjadikan kegiatan belajar mengajar lebih efektif, sehingga tujuan pembelajaran dapat dicapai dengan baik. Model pembelajaran yang tepat dapat membantu siswa untuk memahami materi dengan lebih mudah. Model pembelajaran merupakan alat ukur untuk mencapai tujuan yang ingin dicapai sehingga penggunaan model yang tepat akan berhasil sebagai pencapai tujuan. Tanpa suatu model 
pembelajaran yang jelas, proses pembelajaran tidak dapat berlangsung secara efektif dan efisien, sehingga tujuan pembelajaran yang diinginkan sulit tercapai (Huda, 2015).

Guru dituntut untuk merancang kegiatan pembelajaran yang mampu mengembangkan kompetensi, baik ranah kognitif, ranah psikomotorik, dan ranah afektif. Model pembelajaran kooperatif banyak sekali jenis-jenisnya, guru harus pandai memilih dan memilah model pembelajaran yang tepat. Strategi pembelajaran yang berpusat pada siswa dan menciptakan suasana yang menyenangkan sangat diperlukan untuk meningkatkan hasil belajar siswa dalam mata pelajaran chassis dan pemindahan tenaga. Hal ini merupakan pertimbangan bagi penulis untuk memilih model pembelajaran kooperatif tipe jigsaw.

\section{METODE PENELITIAN}

Metode penelitian yang digunakan dalam penelitian ini adalah model quasi experimental desaign. Untuk menyeleraskan model tersebut, desain yang digunakan adalah nonequivalent control group desaign yang menggunakan pre test dan post test terhadap kelas ekspeimen dan kelas kontrol yang dipilih secara acak. Penelitian ini dilakukan pada dua kelompok, yaitu kelompok eksperimen yang diberikan perlakuan belajar dengan menggunakan model pembelajaran kooperatif tipe jigsaw dan kelas kontrol yang diberikan perlakuan belajar dengan menggunakan model pembelajaran klasikal. Populasi dalam penelitian ini adalah siswa kelas XI TKR SMKN 8 Bandung yang terdiri dari 6 kelas. Sampel yang digunakan pada penelitian ini adalah 2 kelas, yaitu kelas XI TKR 2 untuk kelas kontrol dan XI TKR 3 untuk kelas eksperimen. Kedua kelas ini dikarenakan rata-rata nilai siswa di bawah KBM pada kompetensi dasar perawatan kopling dibandingkan dengan kelas lainnya, jadi penelitian ini di kelas XI TKR2 dan XI TKR3.

\section{HASIL PENELITIAN}

Data diperoleh dari nilai pre test sebelum diberikan pembelajaran kooperatif tipe jigsaw, dan nilai post test setelah diberikan pembelajaran kooperatif tipe jigsaw pada kelas eksperimen dan kelas kontrol. Data tersebut adalah kelas eksperimen 63,83\% menjadi 84,33\% sedangkan kelas kontrol 67,5\% menjadi 83,33\%. Presentasi peningkatan kelas eksperimen $32 \%$ dan kelas kontrol 23\%. Perbedaan hasil pre test dan post test dapat diketahui dari rumurs $\mathrm{N}$-Gain untuk mengetahui hasil kualitas peningkatan kemampuan siswa pada kelas kontrol maupun kelas eksperimen. Sebelum di analisis, data yang awalnya gain diubah dalam bentuk $N$-Gain sesuai dengan rumus yang ditentukan. Pada 
tabel di bawah ini merupakan hasil penelitian yang sudah dalam bentuk $\mathrm{N}$-Gain kelas eksperimen dan kelas kontrol.

Data hasil penelitian pada ranah kognitif kelas eskperimen rata-rata $N$-Gain adalah 0,75 sedangkan kelas kontrol rata-rata $N$-Gain adalah 0,68 . Jika nilai rata-rata $N$-Gain dengan kriteria 0,30 $\leq N-$ Gain $\leq 0,70$, maka nilai pada kelas eksperimen tergolong tinggi yaitu $0,70<0,75$. Sedangkan pada kelas kontrol tergolong sedang yaitu $0,30 \leq$ $0,68 \leq 0,70$. Pada ranah psikomotorik kelas eskperimen rata-rata $N$-Gain adalah 0,4 sedangkan kelas kontrol rata-rata $N$-Gain adalah 0,36 . Jika nilai rata-rata $N$-Gain dengan kriteria $0,30 \leq N-$ Gain $\leq 0,70$, maka nilai pada kelas eksperimen tergolong sedang yaitu $0,30 \leq 0,4 \leq 0,70$. Sedangkan pada kelas kontrol tergolong sedang yaitu $0,30 \leq$ $0,36 \leq 0,70$. Pada ranah afektif kelas eskperimen rata-rata $\mathrm{N}$-Gain adalah 0,27 sedangkan kelas kontrol rata-rata $\mathrm{N}$-Gain adalah 0,31 . Jika nilai rata-rata $\mathrm{N}$-Gain dengan kriteria $0,30 \leq N-$ Gain $\leq 0,70$, maka nilai pada kelas eksperimen tergolong rendah yaitu $0,30 \leq 0,27 \leq 0,70$. Sedangkan pada kelas kontrol tergolong sedang yaitu $0,30 \leq 0,31 \leq$ 0,70 .

Hasil dari pengujian homogenitas pada ranah kognitif, kedua kelas tersebut homogen karena 0,189 > 0,05. Sedangkan ranah psikomotorik didapat nilai signifikansi 0,016 pada taraf signifikansi $\alpha=0,05$. Hasil dari pengujian homogenitas pada ranah psikomotorik, maka dapat disimpulkan kedua kelas tersebut tidak homogen karena 0,016 < 0,05. Pada ranah afektif didapat nilai signifikansi 0,965 pada taraf signifikansi $\alpha=0,05$. Hasil dari pengujian homogenitas pada ranah afektif, maka dapat disimpulkan kedua kelas tersebut homogen karena 0,965 > 0,05. Pengujian normalitas digunakan untuk mengetahui kondisi data apakah berdistribusi normal atau tidak. Hasil dari ranah kognitif data kelas eksperimen didapatkan hasil nilai signifikansi 0,20 dan kelas kontrol didapatkan nilai 0,163. Jika signifikansi $\alpha=0,05$, maka kedua data pada kelas eksperimen dan kelas kontrol dinyatakan normal. Nilai dari kelas eskperimen pada ranah kognitif 0,20>0,05, sedangkan kelas kotrol 0,163>0,05. Hasil dari ranah psikomotorik data kelas eksperimen didapatkan hasil nilai signifikansi 0,20 dan kelas kontrol didapatkan nilai signifikansi 0,20. Jika signifikansi $\alpha=0,05$, maka kedua data pada kelas eksperimen dan kelas kontrol dinyatakan normal. Karena nilai dari kelas eskperimen pada ranah kognitif 0,20>0,05 sedangkan kelas kotrol 0,20 > 0,05. Hasil dari ranah afektif data kelas eksperimen didapatkan hasil nilai signifikansi 0,06 dan kelas kontrol didapatkan nilai signifikansi 0,20. Jika signifikansi $\alpha=0,05$, maka kedua data pada kelas eksperimen dan kelas kontrol dinyatakan normal. 
Nilai dari kelas eskperimen pada ranah kognitif 0,06>0,05 sedangkan kelas kotrol 0,20> 0,05. Pengujian hipotesis dilakukan pada kedua kelas tersebut yaitu ranah kognitif dan ranah afektif $\mathrm{H}_{0}$ ditolak sedangkan ranah psikomotorik $\mathrm{H}_{0}$ diterima. Artinya terdapat perbedaan peningkatan hasil belajar siswa antara kelas eksperimen yang menggunakan pembelajaraan kooperatif tipe jigsaw dengan kelas kontrol yang menggunakan pembelajaraan klasikal.

\section{PEMBAHASAN}

Hasil observasi aktifitas belajar siswa dan kegiatan guru pada proses belajar mengajar di kelas XI TKR 3 SMKN 8 Bandung. Berdasarkan hasil observasi siswa pada kelas eksperimen menunjukkan adanya perbedaan sebelum diterapkan model pembelajaran kooperatif tipe jigsaw dengan setelah diadakan model pembelajaran kooperatif tipe jigsaw. Sebelum diterapkan model pembelajaran kooperatif tipe jigsaw ini hasil yang didapat pada kelas eksperimen dengan jumlah siswa 31 adalah 59\%. Hasil ini karena siswa masuk kelas tidak tepat waktu, siswa tidak terlalu antusias untuk melaksanakan kegiatan proses pembelajaran, tidak menyimak informasi yang disampaikan oleh guru, peneliti masih menemukan adanya siswa yang melakukan aktifitas selain belajar. Selain hasil observasi siswa, peneliti juga melakukan observasi kepada guru pada saat proses pembelajaran berlangsung. Hasil yang didapat dari observasi adalah baik, namun masih banyak kekurangannya (Hamalik, 2002).

Cara mengukur efektivitas adalah menentukan transferbilitas (kemampuan memindahkan) prinsip-prinsip yang dipelajari (Hamdani, 2011). Tujuan dapat dicapai dalam waktu yang lebih singkat dengan strategi tertentu dari pada strategi yang lain, strategi itu efisien. Kemampuan mentransfer informasi atau skill yang dipelajari lebih besar dicapai melalui strategi tertentu dibandingkan strategi lain, strategi tersebut lebih efektif untuk mencapai tujuan.

Efektivitas dalam pembelajaran harus selalu ditingkatkan demi meningkatkan tujuan pendidikan. Oleh karena itu, untuk meningkatkan efektivitas belajar dalam rangka mencapai ketuntasan belajar, seorang guru pandai dalam memilih model yang harus digunakan, salah satu alternatifnya adalah pembelajaran kooperatif. Cooperative learning merupakan suatu model pembelajaran dimana siswa belajar dan bekerja dalam kelompokkelompok kecil secara kaloboratif yang beranggotakan 4-6 orang dengan struktur kelompok heterogen (Slavin, 2014). Pembelajaran kooperatif tipe jigsaw adalah suatu tipe pembelajaran kooperatif yang terdiri dari beberapa anggota dalam satu kelompok yang 
bertanggung jawab atas penguasaan bagian materi belajar dan mampu mengajarkan materi tersebut kepada anggota lain dalam kelompoknya.

Hasil setelah diadakannya model pembelajaran tipe jigsaw adalah adanya peningkatan dengan perolehan 92,32\%. Model pembelajaran ini telah menunjukkan peningkatan, yaitu siswa berantusias dalam mengikuti kegiatan pembelajaran. Siswa mampu mengeluarkan pendapat pada saat berdiskusi, siswa mampu menjelaskan kembali materi yang telah dipelajari, berinteraksi guru dengan siswa serta siswa dengan siswa mulai membaik, siswa mampu menyimpulkan kegiatan pembelajaran. Berdasarkan observasi guru menunjukan hasil sangat baik, dikarenakan guru memberikan motivasi dan apresiasi kepada siswa, adanya perbedaan dalam melaksanakan proses pembelajaran sebelum dan sesudah dilakukan model pembelajaran kooperatif tipe jigsaw, guru sering membimbing siswanya selama proses pembelajaran berlangsung, dan guru sering melaksanakan penilaian dalam proses pembelajaran. Hal ini dapat dilihat pada hasil aktifitas belajar siswa setelah terjadi peningkatan.

Pembelajaran dengan menggunakan model pembelajaran kooperatif tipe jigsaw sudah menunjukkan keefektivitasan pada nilai siswa yang meningkat serta efektivitas siswa yang meningkat dibandingkan dengan sebelum diadakan penelitian. Jadi penggunaan model pembelajaran kooperatif tipe jigsaw pada kompetensi dasar perawatan kopling di SMKN 8 Bandung sangat efektif. Terdapat beberapa aspek yang dapat mempengaruhi tingkat efektivitas, yaitu: aspek fungsi, aspek rencana, aspek aturan dan aspek tujuan (Dimyati dan Mudjiono, 2013). Dikatakan efektif jika melaksanakan tugas dengan baik, begitu juga dalam suatu pembelajaran akan efektif jika tugas atau fungsinya dilaksanakan dengan baik. Dimaksud dengan tugas atau fungsinya adalah tugas seorang guru mengajar dengan baik sehingga peserta didik belajar dengan baik.

Hasil penelitian menunjukkan bahwa kemampuan siswa berupa hasil pre test dan post test mencangkup aspek kognitif, aspek psikomotorik, dan aspek afektif. Oleh karena itu, bahwa hasil belajar siswa kelas eksperimen lebih tinggi dibandingkan kelas kontrol dilihat dari pengujian $N$-Gain. Peningkatan yang signifikan diperoleh dari kelas eksperimen. Kemampuan awal dari kedua kelas tersebut yaitu kelas eksperimen 63,83 sedangkan kelas kontrol 67,5. Setelah mendapatkan perlakuan pada kelas eksperimen diperoleh 84,33 lebih tinggi dibandingkan dengan kelas kontrol 83,33. Dapat disimpulkan bahwa kelas eksperimen lebih tinggi dibandingkan dengan kelas kontrol. Hasil belajar akademik dalam belajar kooperatif meskipun mencangkup beragam tujuan sosial dan memperbaiki prestasi siswa atau tugas-tugas akademik penting lainnya (Isjoni, 2007). 
Model ini unggul dalam membantu siswa memahami konsep-konsep yang sulit. Para pengembang model ini telah menunjukan bahwa model struktur penghargaan kooperatif telah dapat meningkatkan nilai siswa pada belajar akademik dan perubahan norma yang berhubungan dengan hasil belajar. Di samping mengubah norma yang berhubungan dengan hasil belajar, cooperative learning dapat memberi keuntungan, baik pada siswa kelompok bawah maupun kelompok atas yang bekerja bersama menyelesaikan tugas-tugas akademik (Munir, 2010).

Kelas eksperimen lebih tinggi dibandingkan kelas kontrol diperoleh dari hasil $\mathrm{N}$ Gain pada aspek kognitif dan aspek psikomotorik sedangakan aspe afektif cenderung lebih rendah dibandingkan kelas kontrol. Hasil $\mathrm{N}$-Gain dari masing-masing aspek, yaitu aspek kognitif kelas eksperimen 0,75 sedangkan kelas kontrol 0,68, aspek psikomotorik kelas eksperimen 0,4 sedangkan kelas kontrol 0,36, dan aspkek afektif kelas eksperimen 0,27 sedangkan kelas kontrol 0,31. Hasil analisis $N$-Gain pada kelas eksperimen dan kelas kontrol diperoleh rata-rata sebesar 0,84 dan 0,83. $N$-Gain kelas eksperimen 0,84 dinyatakan tinggi sedangkan kelas kontrol 0,83 dinyatakan tinggi. Peningkatan hasil belajar siswa berdasarkan dari aspek kognitif, psikomotorik, dan afektif dapat disimpulkan bahwa kelas eksperimen $32 \%$ sedangkan kelas kontrol $23 \%$.

Model pembelajaran kooperatif tipe jigsaw ini memberikan dampak posistif terhadap peningkatan hasil belajar siswa dibandingkan dengan menggunakan model pembelajaran klasikal. Model pembelajaran kooperatif tipe jigsaw lebih efektif dibandingkan dengan penggunaan model pembelajaran klasikal (Pribadi. 2010).

\section{KESIMPULAN}

Kesimpulan penilitian ini, yaitu: model pembelajaran tipe jigsaw sangat efektivitas dalam meningkatan aktifitas belajara siswa SMK pada ranah kognitif, psikomotorik, dan afektif pada kompetensi dasar perawatan kopling, implementasikan model pembelajaran kooperatif tipe jigsaw dapat meningkatkan hasil belajar siswa SMK pada kompetensi dasar perawatan kopling. Hasil belajar pada kelas eksperimen lebih tinggi dibandingkan dengan kelas kontrol.

\section{DAFTAR PUSTAKA}

Dimyati dan Mudjiono. (2013). Belajar dan pembelajaran. Jakarta: Rineke Cipta. Hamdani. (2011). Strategi belajar mengajar. Bandung: Pustaka Setia.

Hamalik, O. (2002). Mengajar azas model dan teknik. Bandung: Pustaka Karya. 
Huda, M. (2015). Cooperative lerning. Yogjakarta: Pustaka Pelajar.

Isjoni. (2014). Cooperative learning. Bandung: Alfabeta.

Munir. (2010). Kurikulum berbasis teknologi informasi dan komunikasi. Bandung: Alfabeta.

Pribadi. (2010). Model desain sistem pembelajaran. Jakarta: Dian Rakyat.

Slameto. (2013). Belajar dan faktor faktor yang mempengaruhinya. Jakarta: PT.Rineka Cipta.

Slavin, R.E. (2014). Cooperative learning. Bandung: Nusa Media.

Sudjana, N. (2014). Penilaian hasil proses belajar mengajar. Bandung: PT. Remaja Rosda. 